\title{
Effects of Fiscal Policy on the Performance of Real Estate Industry in Kenya
}

\author{
Glories Ilondanga ${ }^{1}$, Tobias Olweny ${ }^{2}$, Ph.D \\ ${ }^{1,2}$ Department of Economics, Accounting and Finance Jomo Kenyatta University of Agriculture and Technology, Nairobi, Kenya \\ Coressponding Author: Glories Ilondanga \\ Department of Economics, Accounting and Finance Jomo Kenyatta University of Agriculture and Technology, Nairobi, Kenya
}

\begin{abstract}
This study mainly sought to investigate the effect of fiscal policy on theperformance of real estate industry in Kenya. The study obtained time series data from the Central bank website and Kenya national bureau of statistics for forty quaters spanning from $2008 \mathrm{Q}_{1}$ to $2017 \mathrm{Q}_{4}$. The study employed a multiple regression analysis using E-views 10 software to determine the influence of these variables on the performance of the real estate industry in Kenya. All the variables were found to be normally distributed and stationery at first difference with absence of econometric problems. Therewere no cointergrating variables in the model.The results of multiple regression analysis indicated that taxation and government expenditure had a positive and significant effect on the performance of the real estate industry while public debt was statistically not significant andhad a negative effect on the real estate performance.Based on the findings,the study recommends that policies that are pro-government expenditure in housing/community development should be supported.
\end{abstract}

Key Words: Fiscal policy, Realestate, Taxation, Government expenditure, Public debt

\section{Introduction}

Fiscal policy is amongst various factors that help determine a country's economic direction. It is mainly actualized by the government to influence the economy by adjusting revenue and the spending levels (Afonso \& Sousa, 2011). The main tools that facilitate fiscal policy are taxes and expenditure, debt is also an aspect of fiscal policy. Taxes influence the economy by determining how much money the government and individuals have to spend. Government expenditure refers to the utilization of finances obtained from local taxes and other sources for the growth and stability of the general economy (Anywanu, 1997). Government expenditure in various sectors boosts the economy by providing employment and increasing production capacities. Debt plays a crucial role in any country's financial system. It is used to finance huge infrastructure development projects as well as bridge fiscal deficits of a country. Cecchetti and Zampolli (2011) posit that high levels of government debt do not cause instability instead it prevents a deeper recession.

This study sought to investigate how these three aspects of fiscal policy relate to the performance of the real estate sector in Kenya. Recently, Kenya has experienced an upsurge of growth in the real estate sector. Knight Frank, a real estate management company, rated Nairobi as an exponentially growing market in the world way ahead of cities like Miami and Monaco in the 2012 Wealth Report. John Lang LaSalle, a global real estate firm also placed Nairobi amongst the top ten cities to watch out for. This report has been supported by the findings of Hass consult, one of Kenya's leading real estate companies, which makes public on a quarterly basis the Hass Property Index. The country's real estate sector has in the recent past experienced exponential growth. The Hass consult property index which enables investors track the performance of the sector has proved this true. The Hass Composite Sales Index is a representative of all properties for sale in Kenya. Property developers have to date not been able to satisfy the steadily increasing demand for property (Lidonga, 2015).The government, through the social pillar of the Vision 2030 on housing, seeks to produce over 200,000 units of housing annually under public private partnerships and other initiatives in order to provide good housing for all citizens. Managing this sector in-order to achieve more in revenue and ensure that housing demand is met will therefore be an interesting balance for the government.

Oates (1969) investigated how local public spending and property taxes affected property value. He discovered that for every increase in property taxes that wasn't accompanied by an equal increase in the output of local public services, the difference of the rise in tax would reduce property. Maina (2014) investigated how income taxes affected the economic performance in Kenya. His study findings revealed that there was a negative but insignificant relationship between income tax and economic performance. Kambua (2014) sought to examine how government expenditure affected Kenya's economic growth. Thefindings revealed that; there was a significant influence of the government expenditure on education, infrastructure, health and defense. Thus it was recommended that; The 


\section{"Effects of Fiscal Policy on the Performance of Real Estate Industry in Kenya"}

government should strongly embark on infrastructure development to reduce the cost of doing business and enhance efficiency in service delivery to accelerate development. Iheanacho (2016) Sought to investigate the contribution of government expenditure to the economic growth of Nigeria. The findings unearthed that Nigeria's main economic driver was recurrent expenditure. For the capital expenditure, this study documents that Nigeria's economic growth experiences a negative and significant long run effect of capital expenditure.

According to Checherita and Rother (2010) a non-linear impact of debt on growth exists, with a turning point beyond which the government debt-to- GDP ratio has a deleterious impact on long term growth. These were their findings in their empirical investigation on the impact of high and growing government debt on the economic growth in the Euro zone. From her investigation on effect of public debt on private investments and economic growth, Kamundia et al. (2015) found out that debt had a negative effect on private investments and a positive effect on economic growth.

A comprehension of the fiscal policy and how its aspects affect performance of the real estate industry in Kenya is therefore necessary. This has been left unaddressed by previous local and international studies. To the best of the researcher's knowledge, there are no studies related to the effect of Fiscal policy on performance of the real estate industry in Kenya. This strengthens the importance of the current study and the value it adds to the existing body of literature. Therefore, this study aims to bridge this gap by investigating the effect of fiscal policy on the performance of real estate industry in Kenya.

\section{General Objective}

This study seeks to establish the effect of fiscal policy on performance of the real estate industry in Kenya.

\section{Specific Objectives}

1) To determine the effect of property tax on the performance of real estate industry in Kenya.

2) To investigate the effect of government expenditure on housing and urban/community development on the performance of real estate industry in Kenya.

3) To establish the effect of Public debt on the performance of real estate industry in Kenya.

\section{Theoretical Review}

\section{Ability to Pay Theory}

Smith (1776) propagated the ability-to-pay theory. The theory states that persons should pay taxes in proportion to their individual capacity; which means that people with higher income should pay more than people with lower income. Kaldor (1956) agreed and asserted that since tax was progressive, this theory would increases tax burden to businesses and individuals who earned more income can afford to pay high amount of tax compared to those earning less income in that they pay less tax. Jack and Milliron (1986) argued that tax fairness encompasses a minimum two dimensions. The first one largely involves the equity of trade vis-a-vis the benefits received for the tax dollars given. The other dimension mainly centers on the equity of the individual taxpayer's burden with respect to the other individuals. In the other words, tax liability among taxpayers should be synchronized with their ability to pay. Those with the same ability to pay must be imposed the same tax liability, while taxpayers who have different ability to pay must be imposed differently. Torgler (2007) argues that this theory of taxation does not take into consideration the amount of these services that taxpayers actually use. For instance, all taxpayers contribute to public schools, even if they do not have any kids in a school system. Smith (2010) recons that it is mandatory for every state to implement the ability-to-pay tax theory in order to contribute revenue to the government. The basic tenet of this theory is that the burden of taxation should be shared by the society on the principles of justice and equity and that these principles necessitate that the tax burden is apportioned according to their relative ability to pay. This theory suggests that the payers of TOT should pay unconditionally and according to paying capacity (Chigbu, Eze and Ebimobowei, 2012).This theory is indeed the most equitable tax system since people with greater income are at a higher rate than those with less individual income tax. This theory has been widely used in industrialized economics.

\section{Peacock and Wiseman Hypothesis}

Peacock and Wiseman (1961) argued that public expenditure does not increase in a smooth and continuous manner, but in jumps and jerks in a step like fashion. Gupta (1967) subjected the displacement hypothesis to empirical testing in case of five countries and found an upward displacement confirming the validity of the hypothesis. Goffman and Mahar (1971) in their study of the growth of public expenditure in six developing Caribbean Countries have found definite evidence of the displacement effect hypothesis. But the source of this 'displacement' appears to differ from those observed in developed countries. Reddy's (1972) Study of the growth of public expenditure in India, from 1872 to 1968 , supports the 'displacement effect' hypothesis. Auld and Miller (1977) observed that when war and related expenditure are deducted from total expenditure for United Kingdom, for the period from 1890 to 1955, the displacement effect vanishes. They, therefore, concluded that the empirical evidence therefore, suggests that wars do not cause displacements but only temporary peaks on a rising trend. Nagrajan (1978) makes an attempt to test the displacement effect hypothesis for central government expenditure In India as a consequence of less pronounced political-social upheaval which he called 'non-global crisis' like the Sino-Indian hostilities of 1962. 
The observation that the crisis did not affect public expenditure in 1961-62, but the impact of the crisis was felt from 1962-63 onwards. Therefore, he finds empirical support for the displacement effect hypothesis in public expenditure associated with hostilities of 1962. O'Hagan (1980) argues that the worldwide recession of 1974-75 might qualify as a major social disturbance as well. But he concedes that the priori arguments for a displacement effect after the 1974-75 recessions are likely to have essentially short-term implications, leading to an initial rise in the public spending ratio due to inertia in adjusting spending plans downwards. Bhatia (2009) also argues that public expenditure rises and makes the inadequacy of the present revenue. This leads to the displacement effect, where the government moves from the old level of expenditure and financing to a higher one. Public expenditure and revenue get stabilized at a new higher level until another shock occurs to cause a displacement effect. Dada and Adesina (2013) attempted to examine the validity of PeacockWiseman hypothesis in case of government expenditure and revenue in Nigeria covering the period 1961 to 2010. It was found that hypothesis holds in the short-run as well as longrun. Government spending induced the growth of public revenue during the reference period.

This theory attempts to explain how government expenditure in Kenya has taken unrelenting upward trajectory. Every time Kenya has experienced shocks like, 1984 famine, resettlement of IDPs, and upsizing of the government structure to accommodate the many ministries intended to serve the citizens, the taxes intensity and scope danced in tandem with the public expenditure.

\section{Debt Overhang Theory}

This theory was first postulated by Myers (1977) with his theory of company valuation in corporate finance and the effects of debt-financing. His paper examines why companies do not finance their activities with maximum debt even though there clearly exists a tax-advantage due to the deductibility of interest rates. The reason, he explains, for this is that high amounts of debt, or debt itself, distorts the possibilities for companies to make optimal future investment decisions. Debt induces a behavior where positive net present value projects are not embarked on due to the fact that a part of future earnings from projects pays off creditors (Myers, 1977)

Krugman (1988) investigated whether debt forgiveness or debt financing is viable in the case of a defaulting developing country. Debt overhang explains a situation in which a country's ability to repay its debt falls below falls below the contractual value of debt. Cohen's (1993) theoretical model posits a non-linear impact of foreign borrowing on investment as suggested by Clements et al. (2003) who indicates that this relationship can be arguably extended to growth. Thus, up to a certain threshold, foreign debt accumulation can promote investment, while beyond such a point the debt overhang will start adding negative pressure on investors' willingness to provide capital.

Deshpande (1997) studied the SICs and sampled thirteen of them to investigate how their economies behaved during 1971-1991. Her regression established a negative influence on investments by the presence of a large debt. She also used a time variable to separate the debt effect from other effects. The time variable had up until 1984 a positive effect on investments while between 1984 and 1991 that effect turned largely negative as a response on the changed investment climate. There is critique relating to the research field of debt overhang and its effects on country growth through the channel of investments. Karagöl (2002) in his summary of the state of knowledge in the debt overhang research field. He concluded that there are country differences and that no theory of debt overhang can be applied to all countries unilaterally, each country is a special case due to social, economic and political differences.

Public debt being a burden for generations to come may be the case in Kenya as it is expected that the money borrowed today will be paid latter with interest. However, it remains to be seen if public debt reduces the available lifetime consumption. This is because if the money is invested in income generating project the public debt may not reduce the available lifetime consumption. The debt overhang theory applies to Kenya since there is a probability that forthcoming indebtedness will outgrow the repayment capability of the country. There is need for further study to be done to verify whether the anticipated servicing of the debt expenses will deter more internal and external investment.

\section{Empirical Review}

Njuru et al. (2013) carried out an empirical research to determine the impact of taxation on private investment in Kenya. Time series data spanning 1964-2010 and a descriptive research design were employed. Recursive Vector auto-regression technique was used to achieve the study objectives. The results showed that income tax and value added tax deterred private investment. However, the effect of income tax was short lived but that of value added tax persisted. The findings further indicated that excise duty and import taxes had mixed outcomes on private investment. However, the effect was more on positive territory, which led to a conclusion that these taxes promoted private investment. The results further revealed that establishment of KRA in 1995 had a negative effect on private investment in Kenya. Tax amnesty was found to be encouraging private investment.

Kanini (2013) In order to determine the effect of the tax reforms to the financial performance of real estate firms, descriptive sample survey research design was used to measure the effect of tax reforms on financial performance of real estate firms. The population for this study comprised 197 real estate firms which had been registered between 2009- 2012 in Kenya, are operational and have annual 
turnover in excess of Kshs.500 Million.44 real estate firms which had been registered between 2009 and 2012 had a turnover in excess of Ksh 500 Million were used as study sample. The results revealed that tax reforms positively affected the financial performance of the real estate firms in Kenya. However, those effects are rather weak. Of the determinants explored, experience in the implementation of tax reforms, filling of returns on-line and tax relief present the most influencing positive effect on the financial performance of the real estate firms; with implementation of tax reforms taking the most single important position in influencing financial performance.

Kambua, (2014) carried out an empirical research to establish the effect of government spending on economic growth in Kenya. The study was descriptive and involved quantitative analysis of data which employed secondary data to analyze the effect of government expenditure on economic growth in Kenya. Time series data for economic growth was obtained from World Bank and IMF data bank from 2007 to 2012.Components of government spending includes: health, education, infrastructure and security. Granger Causality Test was used to determine whether one time series is useful in forecasting another. The VAR equations were used to perform Granger causality tests. The study findings indicated that; there is a significant influence of the government spending on education, infrastructure, health and defense.

Muigai (2016) investigated the impact of government spending on Kenya's GDP. The research employed a descriptive study of selected government functions in Kenya. The population of the research encompassed four ministries and they include the ministry of agriculture, health, security and defense, and education. Purposive sampling was used due to the convenience purposes as the research understood the target population. Time series data spanning from 2005-2015 was gathered. A multivariate regression model was applied to establish the impactof spending by the government on GDP and was tested through the use of SPSS software. The results indicated thatthe regression model was overall statistically significant, meaning that it is a suitable prediction model for explaining how government expenditures to different functions adds value to gross domestic product with expenditures on health being a suitable predictor of gross domestic product.

Were (2001) used the OLS technique to examine the structure of Kenya's external debt and its implications on economic growth. A descriptive design and time series data spanning from 1970-1995 was adopted. The results of data analysis and estimation were obtained using the Generalized Instrumental Variables Estimators econometrics computer package (PC-GIVE, version 8.0). The study explained that Kenya's external debt was mainly official with a large proportion is from multilateral sources. The findings of the time series data also elaborated that external debt accumulation negatively impacted economic growth and private investment. This confirmed the existence of a debt overhang problem in Kenya. However, the results also indicated that current debt inflows stimulate private investment.

It is evident from the foregoing empirical literature that most studies have not addressed how components of fiscal policy affect performance of the real estate industry. This means that there is scanty empirical evidence on the topic in study. This study therefore sought to provide detailed resource material and contribute significantly to the body of literature. Relevant diagnostic tests were also conducted to avoid a spurious regression and identify presence of econometric problems before the model was considered fit for inferential analysis. The OLS technique0 was preferred because of the strong and sufficient theoretical evidence linking the variables.

\section{Research Methodology}

The study adopted a descriptive research design. Mugenda and Mugenda (2003) describes descriptive research design as a systematic, empirical inquiring into which the researcher does not have a direct control of independent variable as their manifestation has already occurred or because the inherently cannot be manipulated. Descriptive studies are concerned with the what, where and how of a phenomenon hence more placed to build a profile on that phenomenon (Mugenda \&Mugenda, 2003). Descriptive research design is more appropriate because the study sought to build a profile about the relationship between fiscal policy and performance of real estate industry. Furthermore, Gacanja (2012), Njuru et. al. (2013) and Muigai (2016) from empirical review have embraced this design.

\section{Population}

The study adopted time series data for three economic variables for the period from $2008 Q_{1}$ to $2017 Q_{4}$. This study concentrated on the following variables; dependent variable, performance of real estate (measured by the Hass consult index) and independent variables namely government expenditure, taxation and public debt.

\section{Sample Size}

In the words of Mugenda and Mugenda (2003) "Sampling is the procedure of choosing a number of individuals for a study in such a way that the individuals selected are representative of the large group from which they were selected". Sampling was not utilized since this was a case study.

\section{Data Collection}

Secondary data for the period $2008 Q_{1}$ to $2017 Q_{4}$ was utilized to analyze the effect of fiscal policy on performance of the real estate in Kenya. This data was obtained through analysis of documents. A deliberate effort was made to ensure consistency in source for all the series. But should the preferred series not give all the information needed, other sources would be referred and data converted 
where necessary to reflect the form in which they would be useful for estimation purpose in this study.

The sources of data for government expenditure and public debt were Kenya National Bureau of Statistics and the National treasury. Data for public debt was obtained by adding the values of external and internal debt for each year. Data on taxation was collected from LATF (Local Authority Transfer Fund) reports in various economic surveys. Hass consult provided data on the performance of the real estate as measured by the Hass consult sales index.

\section{Data Analysis and Presentation}

Before subjecting the data to a regression analysis, descriptive statistics test were conducted to provide a general view of the distribution and behavior of the variables in use. Residual test for normality of the data series were conducted and the Jacque Bera coefficient and its p-value be observed for significance. The statistical package E-view version 10 was used for analysis. For the above analysis and for obvious statistical reasons, the logs (L) of all the variables were calculated. The regression equation was as follows;

$$
\mathrm{LPRE}=\beta_{0}+\beta_{1} \mathrm{LTXN}+\beta_{2} \mathrm{LGE}+\beta_{3} \mathrm{LPD}++\varepsilon_{\mathrm{t}}
$$

Where;

PRE- Performance of Real estate

TXN- Taxation

GE- Government expenditure

PD-Public Debt

$\beta 1, \beta 2, \beta 3$, Coefficients of PRE with respect to TXN, GE, and PD

$\beta 0,-$ constant term

$\varepsilon_{\mathrm{t}}$-Error term

\section{Statistical Tests \\ Unit Roots}

Presence of Stationarity in data may ultimately result in inconsistent regression. A series is stationary if its mean and variance are independent of time, and it is integrated of order zero, A non-stationary series has time dependent mean and variance, and its order of integration is one or higher. Presence of stationarity indicates long run relationship between the dependent variable and regressor. Augmented Dickey Fuller (ADF) test was used to test for stationarity. The ADF tests the null hypothesis that where; ADF value $<$ Critical value $=$ Unit root exist, Non-stationery data against an alternative that where $A D F$ value $>$ Critical value $=$ No unit roots, Stationery data.

\section{Cointegration Test}

The co-integration theory argues that although the variables in a model are Non-stationary at level I (0) the linear relationship among them may still be stationary at difference I (1) (Johansen and Juselius, 1990). The studyadopted the Johansen's cointegration test to examine whether thevariables in the model have long run relationship amongst themselves. The outstanding advantage of this method is that it has the ability to test for several cointegrating vectors when the variables are more than two and it incorporates a joint procedure of testing the maximum likelihood estimation of vector error correction model and long run equilibrium relationship. Hence when the Trace statistic > Critical value we reject the Null. When Trace statistic $<$ Critical value we accept the Null.

\section{Diagnostic Tests \\ Test for Normality}

The normality test for the computed residual and on the regression variables were performed using the Jarque-Bera (JB). The (JB) test directly tests the error term distribution and the variables. As can be noted, the efficiency and consistency of OLS estimator is on the basis of normality distribution of the error-terms. The (JB) uses the first four moments of distribution (mean, standard deviation, skewness and excess Kurtosis) along with the minimum and maximum values of the series to construct a distribution, which can then be compared against the equivalent value, produced by the standard normal distribution. JB test was performed on all the explanatory variables to investigate the extent to which they could affect the results obtained. The null hypothesis will be that the variables are normally distributed.

\section{Test for Heteroscedasticity}

Heteroscedasticity is a situation where the error terms do not have constant variance. Heteroscedasticity produces a bias in test statistics and confidence intervals. One major regression assumption is that the variance of the errors is constant across observations. If the errors have constant variance, the errors are called homoscedastic. Typically, residuals are plotted to assess this assumption. Standard estimation methods are inefficient when the errors are heteroskedasticor have non-constant variance .To test for heteroscedasticity situations, Breuch-Pagan test was used. If heteroscedasticity is present, it can be corrected using robust standard errors

\section{Test for Multicollinearity}

Multicollinearity problem can occur where some or all of the independent variables are highly correlated with each other. If there is multicollinearity problem in the model, the regression model would have difficulty to determine which independent variables are influencing the dependent variable. Multicollinearity was detected by examining the correlation matrix provided by E-views software version 10 . Where there is any correlation between two variables exceeding $80 \%$, then serious multicollinearity can be suspected. In this study, we used correlation matrix to detect the seriousness of multicollinearity. If there is no serious multicollinearity in the model, the estimated parameters would be unbiased, efficient and consistent which is best linear unbiased estimator (BLUE). In contrast, if there is serious multicollinearity in the model, the estimated 
parameters would be unbiased, inefficient and consistent which is no longer BLUE (Gujarati, 2009)

\section{Test for Serial Correlation}

Time-series data often displays serial correlation of the disturbances across periods (Green, 2008).Serial correlation is problematic to linear data models because its presence renders the standard errors biased as well as making the estimated regression coefficients consistent but inefficient (Drukker, 2003; Baltagi, 2005).The Breusch -Godfrey serial correlation LM test was adopted for this study. The null hypothesis for the LM test is that there is no serial correlation .If the p-value of the Observed R-squared is more than 0.05 , the study fails to reject the null and concludes that the errors in different observations are not correlated with each other (Durbin \&Watson, 1971)

\section{Statistical Test of Significance}

The F-test was used to establish the models overall significance.

$\mathrm{H}_{0}$ : The overall model is not significant

$\mathrm{H}_{1}$ : The overall model is significant

Where the probability of the F-statistic is less than significance level $0.05(5 \%)$ then the $\mathrm{H}_{0}$ is rejected and conclude that the overall model is significant. Otherwise, we do not reject $\mathrm{H}_{0}$ and conclude that the overall model is not significant. The coefficient of determination, $\mathrm{R}^{2}$ was used to determine how much variation in $\mathrm{Y}$ (response variable) was explained by $\mathrm{X}$ (predictor/explanatory variable). This was done at $5 \%$ significance level.

\section{Model specification}

The model is in the form of a regression equation where all the indicators of fiscal policy were regressed against performance of the real estate using the OLS technique. The model is a multiple linear regression of the form;

$Y=\beta_{0}+\beta_{1} X_{1}+\beta_{2} X_{2}+\beta_{3} X_{3}+\varepsilon_{t}$

Where: $\mathrm{Y}=$ ) Performance of real estate (Measured by Hass consult sales index)

$\mathrm{X}_{1}=$ Taxation (measured by the $\%$ annual change)

$\mathrm{X}_{2}=$ Government expenditure (measured by the $\%$ annual change)

$\mathrm{X}_{3}=$ Public Debt (measured by the $\%$ annual change)

$\beta_{1}, \beta_{2}$ and $\beta_{3}=$ partial coefficients of Real estate performance with respect to $\mathrm{X} 1, \mathrm{X} 2$ and $\mathrm{X} 3$ respectively

$\varepsilon=$ Stochastic error term. It captures the effect of other factors other than fiscal policy instruments on the performance of real estate industry and helps in stabilizing the model.

$\beta_{0}=$ Constant term

\section{Result and Discussion \\ Descriptive Statistics}

Table 4.1 below summarizes the descriptive statistics of the variables included in the regression model as presented. It represents the variables; sales index, taxation, government expenditure and public debt from $2008 Q_{1}$ to $2017 Q_{4}$. From the table the mean statistic of each variable is almost equivalent to the median statistic of the same variable indicating that the distribution is symmetrical. The level of skewness was close to zero as shown in table 4.1 below an indication of normal distribution of the variables under study. The Kurtosis value is closer to three indicating that the data exhibits a normal distribution. The total observations of forty relate to the number of quarters used in the study from $2008 Q_{1}$ to $2017 Q_{4}$.

Table 4.1 Descriptive Statistics for Independent and Dependent Variables

\begin{tabular}{|c|c|c|c|c|}
\hline & SALS INDEX & TAXATION & GOVERNM & $P U B \| C, D F B T$ \\
\hline Mean & 2.922500 & 5.486750 & 5.132000 & 5.069750 \\
\hline Median & 2.425000 & 5.560000 & 5.250000 & 5.045000 \\
\hline Maximum & 5.670000 & 8.940000 & 7.530000 & 6.370000 \\
\hline Minimum & 1.400000 & 1.750000 & 1.980000 & 3.660000 \\
\hline Std. Dev. & 1.292100 & 1.961358 & 1.411701 & 0.783266 \\
\hline Skewness & 0.665043 & -0.339907 & -0.538277 & -0.038815 \\
\hline Kurtosis & 2.301631 & 2.133062 & 2.772161 & 1.964591 \\
\hline Jarque-Bera & 3.761412 & 2.022880 & 2.018132 & 1.796828 \\
\hline Probability & 0.152482 & 0.363695 & 0.364559 & 0.407215 \\
\hline Sum & 116.9000 & 219.4700 & 205.2800 & 202.7900 \\
\hline Sum Sq. Dev. & 65.11135 & 150.0301 & 77.72304 & 23.92670 \\
\hline Observations & 40 & 40 & 40 & 40 \\
\hline
\end{tabular}

\section{Statistical Test \\ Unit Root}

The Augmented Dickey-Fuller (ADF) test was adopted to identify the stationary trend of time series data. The null hypothesis $\mathrm{H}_{0}$ states that data has a unit root and alternative hypothesis $\mathrm{H}_{1}$ states that data does not contain a unit root. ADF test helps calculate t-statistic and probability to compare it with critical values at levels and at the first difference with constant or with constant and trend. If the outcomes confirm that critical values are more than t-value at levels, we accept $\mathrm{H}_{0}$ that means the data is non-stationary. At the first difference, if the t-values are greater than the critical values we reject $\mathrm{H}_{0}$ that means the data is stationary. Table 4.2 shows the results of the unit root tests stating that the null hypothesis of no unit root is accepted at level as the value of $\mathrm{ADF}$ is less than the critical values for all variables at level. The results are different at first difference since the ADF values are more than the critical values for all variables. This means $\mathrm{H}_{0}$ is rejected at the first difference. Therefore, we conclude that all the variables under consideration are stationary at first difference with intercept and both trend and intercept. 
Table 4.2 ADF-Unit Root Test

\begin{tabular}{|c|c|c|c|c|}
\hline Variable & & Intercept & Intercept \& Trend & Inference \\
\hline LSales_Index & ADF & -1.734870 & -1.554109 & \\
\hline \multirow[t]{2}{*}{ At Level } & $5 \%$ & -2.938987 & -3.529758 & \\
\hline & P-value & 0.4063 & 0.7927 & Non-Stationary \\
\hline \multicolumn{5}{|c|}{ At $1^{\text {st }}$ Difference } \\
\hline & ADF & -6.753226 & -6.895656 & \\
\hline & $5 \%$ & -2.941145 & -3.533083 & \\
\hline & P-value & 0.0000 & 0.0000 & Stationary \\
\hline LTaxation & ADF & -2.247664 & -2.494207 & \\
\hline \multirow[t]{2}{*}{ At Level } & $5 \%$ & -2.938987 & -3.529758 & \\
\hline & P-value & 0.1936 & 0.3291 & Non-Stationary \\
\hline \multicolumn{5}{|c|}{ At $1^{\text {st }}$ Difference } \\
\hline & ADF & -6.423170 & -6.614285 & \\
\hline & $5 \%$ & -2.941145 & -3.533083 & \\
\hline & P-value & 0.0000 & 0.0000 & Stationary \\
\hline \multicolumn{5}{|c|}{ LGovernment_Expenditure } \\
\hline \multirow[t]{3}{*}{ At Level } & ADF & -0.775104 & -0.763104 & \\
\hline & $5 \%$ & -2.938987 & -3.529758 & \\
\hline & P-value & 0.8150 & 0.905 & Non-Stationary \\
\hline \multicolumn{5}{|c|}{ At $1^{\text {st }}$ Difference } \\
\hline & ADF & -5.257027 & -5.342062 & \\
\hline & $5 \%$ & -2.941145 & -4.219126 & \\
\hline & P-value & 0.0001 & 0.0005 & Stationary \\
\hline \multicolumn{5}{|c|}{ LPublic_Debt } \\
\hline \multirow[t]{3}{*}{ At Level } & ADF & -1.981987 & -2.215957 & \\
\hline & $5 \%$ & -2.941145 & -3.533083 & \\
\hline & P-value & 0.2932 & 0.4676 & Non-Stationary \\
\hline \multicolumn{5}{|c|}{ At $1^{\text {st }}$ Difference } \\
\hline & ADF & -4.771375 & -4.701825 & \\
\hline & $5 \%$ & -2.941145 & -3.533083 & \\
\hline & P-value & 0.0004 & 0.0029 & Stationary \\
\hline
\end{tabular}

\section{Johansen Test for Co-integration}

The co-integration theory argues that although the variables in a model are Non-stationary at level I (0) the linear relationship among them may still be stationary at difference I (1) (Johansen and Juselius, 1990). Table 3 below displays the results of Johansen co-integration test. Based on the outcome, there is no co-integrated equation since the Trace test and Max-Eigen values are lower than the critical values. This means there is absence of any long run relationship among the variables under consideration.

Table 4.3 Johansen Cointegration Test

Date: $10 / 10 / 18$ Time: $15: 57$
Sample (adjusted): 2008 Q $32017 Q 4$
Included observations: 38 a ter adjustments
Trend assumption: Linear determ in istic trend
Series: LSALES_INDEXLTAXATION LGOVERN MENT_EXPENDITU RE LPUBLIC...
Lags interval (in first differences): 1 to 1

Unrestriced Cointegration Rank Test (Trace)

\begin{tabular}{|ccccc}
\hline $\begin{array}{c}\text { Hypothesized } \\
\text { No. of CE(s) }\end{array}$ & Eigenvalue & $\begin{array}{c}\text { Trace } \\
\text { Statistic }\end{array}$ & $\begin{array}{c}0.05 \\
\text { Critical Value }\end{array}$ & Prob. $^{\text {.* }}$ \\
\hline \hline None & 0.323983 & 33.60169 & 47.85613 & 0.5237 \\
At most1 & 0.248205 & 18.72325 & 29.79707 & 0.5129 \\
At most2 & 0.171769 & 7.882170 & 15.49471 & 0.4781 \\
At most3 & 0.018784 & 0.720589 & 3.841466 & 0.3959 \\
\hline \hline
\end{tabular}

Trace test indicates no cointegration at the 0.05 level

" denotes rejection of the hypothes is at the 0.05 level

${ }^{* *}$ Mackinnon-Haug-Michelis (1999) p-values

\section{Regression Analysis}

The dependent variable for this study was performance of the real estate industry in Kenya, which was measured by sales index as provided by Hass consult. It was regressed against; Taxation, Government expenditure and Public debt. The Multiple Ordinary Least Squares model is represented in table 4.4 below.

Table 4.4 E-views Estimation Model Output

\begin{tabular}{|c|c|c|c|c|}
\hline \multicolumn{5}{|l|}{$\begin{array}{l}\text { DependentVariable: LSALES_INDEX } \\
\text { Method: Least Squares } \\
\text { Date: } 10 / 10 / 18 \text { Tim e: } 16: 00 \\
\text { Sam ple: } 2008 \text { Q1 } 201704 \\
\text { Included observations: } 40\end{array}$} \\
\hline Variable & Coefficient & Std. Error & A-Statistic & Prob. \\
\hline LTAXATION & 0.841736 & 0.072252 & 11.65008 & 0.0000 \\
\hline LGOVERNMENT_EXPENDITURE & 0.752783 & 0.080736 & 9.323976 & 0.0000 \\
\hline LPUBLIC_DEBT & -0.309276 & 0.201280 & -1.536548 & 0.1331 \\
\hline $\mathrm{C}$ & -1.083362 & 0.288992 & -3.748765 & 0.0006 \\
\hline R-squared & 0.869656 & \multicolumn{2}{|c|}{ Mean dependentvar } & 0.979390 \\
\hline Adjusted R-squared & 0.858794 & \multicolumn{2}{|c|}{ S.D. dependent var } & 0.436095 \\
\hline S.E. of regression & 0.163873 & \multicolumn{2}{|c|}{ Akaike in fo criterion } & -0.684809 \\
\hline Sum squared resid & 0.986759 & \multicolumn{2}{|c|}{ Schwarz criterion } & -0.515921 \\
\hline Log likelihood & 17.69618 & \multicolumn{2}{|c|}{ Hannan-Quinn criter. } & -0.623744 \\
\hline F-statistic & 80.06412 & \multirow{2}{*}{\multicolumn{2}{|c|}{ Durbin-Wats on stat }} & 1.319898 \\
\hline Prob(F-statistic) & 0.000000 & & & \\
\hline
\end{tabular}

An $\mathrm{R}^{2}$ of 0.869656 from the above output shows that the predictor variables; taxation, government expenditure and public debt account up to $86.97 \%$ of the changes in performance of real estates in Kenya while $13.03 \%$ of the changes in performance of the real estates in Kenya are accounted for by other factors other than those explained above. The difference between R-squared and the adjusted $\mathrm{R}$-squared are not far apart with a margin of $0.09 \%$ This is an indication of low penalty of the adjusted $R^{2}$ on the overall $\mathrm{R}^{2}$ since 2 out of 3 of the explanatory variables were found to be statistically significant in explaining performance of real estate in Kenya.

\section{Diagnostic Tests}

\section{Normality Test of Residual}

A histogram of the residuals is vital in providing a graphical representation of the behavior of the random variables of estimation. As illustrated in Fig.1 below, a Jarque-Bera value of 0.889556 and a probability of 0.640967 which is greater than $5 \%$ significance level is an indication that the residual error terms are normally distributed. Hence the null hypothesis of normality is not rejected. 
"Effects of Fiscal Policy on the Performance of Real Estate Industry in Kenya"

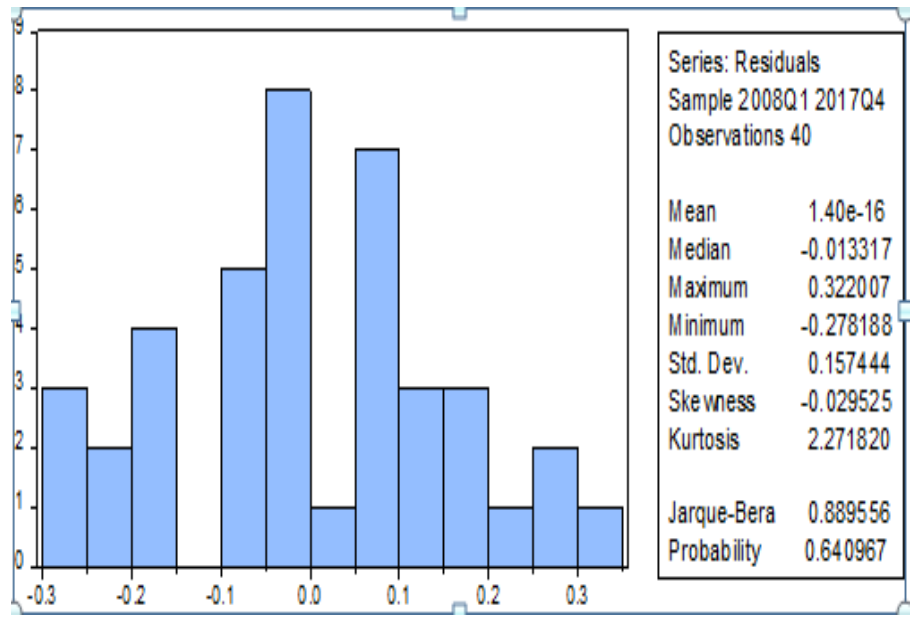

Fig 4.1 Histogram of Residuals

\section{Serial Correlation}

The Breausch-Pagan-Godfrey LM test was adopted to test for serial correlation. The null hypothesis for the LM test is that there is no serial correlation .If the p-value of the Observed R-squared is more than 0.05 , the study fails to reject the null and concludes that the errors in different observations are not correlated with each other.From the results in table 4.5 below the null hypothesis is accepted since the p-value of the R-squared 0.0896 is greater than $5 \%$.

Table 4.5 Serial Correlation LM Test

\begin{tabular}{|lll|}
\hline Breusch-Godfrey Serial Correlation LIM Test: & \\
Null hypothesis: No serial correlation at up to 2 lags \\
\hline \hline
\end{tabular}

\section{Multicollinearity}

The Logic behind the assumption of no multicollinearity is that if two or more independent variables are correlated with each other, one of them should be dropped from the list of variables. In order to check multicollinearity among independent variables, a correlation analysis was performed. The suggested rule of the thumb is that if the pair wise correlation between two regressors is very high, in excess of 0.8 , multicollinearity may pose serious problem (Adam \&Twenoboah, 2008). The worst consequence of multicollinearity is that it increases the variances and standard errors of the OLS estimates. High variances mean that the estimates are imprecise, and therefore not very reliable. High variances and standard errors imply low tstatistics (Granger, 2001). Table 4.5 below depicts correlation matrix results of multicollinearity test showing the relationships between explanatory variables. Based on the results shown in table 4.6 below, all the correlation coefficients between the explanatory variables were less than 0.8 in absolute terms (to one decimal place) and thus qualify the use of Gaussian (ordinary) regression since there is no severe multicollinearity problem (serial correlation) between the variables.

Table 4.6 Correlation Matrix of Explanatory Variables

\begin{tabular}{|c|c|c|c|c|}
\hline $\begin{array}{l}\text { Covarian } \propto \text { Analysis } \\
\text { Date: } 10 / 10 / 18 \text { Time } \\
\text { Sam ple: } 20080120 \\
\text { Included observation }\end{array}$ & $\begin{array}{l}\text { Drdinary } \\
16: 10 \\
Q 4 \\
: 40\end{array}$ & & & \\
\hline $\begin{array}{l}\text { Correlation } \\
\text { t-Statistic }\end{array}$ & LSALES IN ... & LTAXATION & LGOVERN M... & LPUBLIC D.. \\
\hline LSALES_INDEX & 1.000000 & & & \\
\hline LTAXATION & $\begin{array}{l}0.744860 \\
6.881709\end{array}$ & 1.000000 & & \\
\hline LGOVERNMENT_.. & $\begin{array}{l}0.499772 \\
3.556867\end{array}$ & $\begin{array}{l}-0.070212 \\
-0.433888\end{array}$ & 1.000000 & \\
\hline LPUBLIC_DEBT & $\begin{array}{l}0.412257 \\
2.789392\end{array}$ & $\begin{array}{l}0.543895 \\
3.995446\end{array}$ & $\begin{array}{l}0.112234 \\
0.696254\end{array}$ & $\begin{array}{r}1.000000 \\
-\end{array}$ \\
\hline
\end{tabular}

\section{Heteroscedasticity}

Heteroscedasticity tests were done on the residuals using Breusch-Pagan-Godfrey specification to determine homoscedasticity. The Breusch-Pagan-Godfrey regresses squared residuals on the original regressors by default. Where the obtained p-value is more than $5 \%$ significance level, then the model does not have heteroscedasticity problem. The null hypothesis was that there was no heteroscedasticity problem. If the p-value is less than significance level of $0.05(5 \%)$, then we reject the null hypothesis, otherwise do not reject the null hypothesis and conclude that there is heteroscedasticity problem.

The Breusch-Pagan-Godfrey test in table 4.7 below establishes that the model does not have heteroscedasticity problem since the p-values were greater than the significance value of $5 \%$. Hence we fail to reject the null hypothesis and conclude that there is no heteroscedasticity problem.

Table 4.7 Breusch-Pagan-Godfrey Test Heteroskedasticity Test: Breusch-Pagan-Godfey Null hypothesis: Homoskedasticity

\begin{tabular}{llll}
\hline \hline F-statistic & 0.228011 & Prob. F(3,36) & 0.8763 \\
Obs*R-Squared & 0.745863 & Prob.Chi-Square(3) & 0.8624 \\
Scaled explainedSS & 0.384185 & Prob. Chi-Square(3) & 0.9435 \\
\hline
\end{tabular}

\section{Estimation of the Dependent Variable}

From the output in table 4.4 above, the following regression equation (equation 4.1) was established: $\mathbf{Y}=\boldsymbol{\beta}_{\mathbf{0}}+\boldsymbol{\beta}_{\mathbf{1}} *$ Taxation $+\boldsymbol{\beta}_{\mathbf{2}} *$ Government Expenditure $+\boldsymbol{\beta}_{\mathbf{3}}$ *Public Debt $+\varepsilon_{\mathbf{t}} \ldots$ Equation 4.1

By including the coefficients from the regression in table 4.4 we have equation 4.2 
$Y=-1.083362+0.841736 *$ Taxation+0.752783*Government

Expenditure-0.309276*Public Debt $+\boldsymbol{\varepsilon}_{\mathbf{t}} \ldots \ldots$...Equation 4.2

\section{Summary of Findings}

The key finding of this study was that Fiscal policy entirely affects performance of the real estate industry.Taxation and government expenditure were statistically significant at $5 \%$ significance level while public debt was not statistically significant. The diagnostic tests carried out revealed that the model had no incidences of heteroscedasticity, multicollinearity and autocorrelation. The result of F-test indicated that taken together taxation, government expenditure and public debt were significant determinants of real estate performance. This therefore implies that more focus should be put on taxation and government expenditure in housing because they are the significant variables.

\section{Conclusion}

Backed by the empirical findings of this study as documented, a number of logical conclusions were drawn.

First,the Kenyan government, through its legislative arm should support policies that are pro-government expenditure in the housing and community/urban development sectors. Such expenditure would entail funding of road networks, electricity connectivity, water provision and health care infrastructure. The expenditures must be sound and within limits.

Secondly,In order to reflect the ability-to-pay on property taxes, Kenya Revenue Authority should established progressive property rates. The basic idea is to have progressive rates for different classes of income since income inequality is a social problem in Kenya. This approach will represent an effective improvement in the property tax equity and increase rates collection.

Finally, The management of real estate firms should ensure that they timely comply with their tax remittance and filing of property rate to avoid penalties. They should continuously take advantage of government expenditure in housing and scout for new and affordable market products that suit the changing needs of the population. This will greatly diversify their portfolio and increase their asset base.

\section{Suggestions for Further Research}

Future research can be carried out using long period data, and VAR methodology applied if cointegrating variables are identified.

Secondly, This study adopted the Return on Sales method as a measure of performance captured in the Hass consult index, futureresearch can be carried out on the same topic using Return on Asset (ROA) and Return on Investment (ROI) as a measure of performance of real estate.

\section{References}

1. Afonso, A., \& Sousa, R. M. (2011). What are the effects of fiscal policy on asset markets?. EconomicModelling, 28(4), 1871-1890
2. Alshahrani, S. a., \& Alsadiq, AJ (2014). Economic Growth and Government Spending in Saudi Arabia: an Empirical Investigation. IMF Working Papers, 14(3), 1.

3. Anyanwu, J. C. (1997). Nigerian public finance. Joanee Educational Publishers Ltd..

4. Babu, J. O., Kiprop, S., Kalio, A. M., \&Gisore, M. (2014). External debt and economic growth in the East Africa community. African Journal of Business Management, $8(21), 1$.

5. Cecchetti, S. G., Mohanty, M. S., \& Zampolli, F. (2011). The real effects of debt.

6. Charlot, S., Paty, S., \&Visalli, M. (2013). Assessing the impact of local taxation on property prices: a spatial matching contribution. Applied Economics, 45(9), 1151-1166.

7. Checherita, C., \& Rother, P. (2010). The Impact of High and Growing Government Debt on Economic Growth: An Empirical Investigation for the Euro Area (ECB Working Paper Series No. 1237). Frankfurt: ECB. Retrieved December 20, 2012.

8. Chigbu, E. E., \& Eze, L. (2012). An empirical study on the causality between economic growth and taxation in Nigeria. Current research journal of Economic Theory, 4(2), 29-38.

9. Clements, M. B. J., Nguyen, T. Q. \& Bhattacharya, M. R. (2003). External debt, public investment, and growth in low-income countries (No. 3-249). International Monetary Fund.

10. Cohen, D. (1993). Low Investment and Large LDC Debt in the 1980's. The American Economic Review, 437-449.

11. Dada, M. A., \& Adewale, O. A. (2013). Is Wagner's law a myth or a reality? Empirical evidence from Nigeria. International Journal of Development and Economic Sustainability, 1(1), 123-137.

12. Deshpande, A. (1997). The debt overhang and the disincentive to invest. Journal of Development Economics, 52(1), 169-187.

13. Gacanja, E. W. (2012). Tax revenue and economic growth: an empirical case study of Kenya. Unpublished MBA Project, University of Nairobi.

14. Goffman, I. J., \& Mahar, D. J. (1971). The Growth of Public Expenditures in Selected Developing Nations: Six Caribbean Countries 1940-65. Public Finance $=$ Finances publiques, 26(1), 57-74.

15. Gupta, S. P. (1967). PUBLIC EXPENDITURE AND ECONOMIC GROWTH A TIME-SERIES ANALYSIS. PUBLIC FINANCE-FINANCES PUBLIQUES, 22(4), 423-454.

16. Hasnul, A. G. (2015). The effects of government expenditure on economic growth: the case of Malaysia. MPRA Paper No 71254. https://mpra.ub.unimuenchen.de/71254/1/MPRA_p aper_71254.pdf. 
17. Jackson, B. R., \& Milliron, V. C. (1986). Tax compliance research: Findings, problems, and prospects. Journal of accounting literature, 5(1), 125-165.

18. Kamundia, S.W., Gitahi, S. and Mwilaria, S.M. (2015), "The effects of public debt on private investments in Kenya (1980-2013)", International Journal of Development and Sustainability, Vol. 4 No. 8, pp. 860-871.

19. Kambua N.I. (2014),Effects of government spending on economic growth in Kenya. Unpublished masters of science project. University of Nairobi, Kenya

20. Karagöl, E. (2002). The Causality Analysis of External Debt Service and GNP: The Case of Turkey. Central Bank Review 1:39-64.

21. Krugman, P. (1988). Financing vs. forgiving a debt overhang. Journal of development Economics, 29(3), 253-268.

22. Karanja G.K (2013), Relationship between domestic debt and interest rate in Kenya. Unpublished masters thesis. University of Nairobi, Kenya

23. KOBEY, G. L. (2016). EFFECT OF PUBLIC DEBT ON ECONOMIC GROWTH IN KENYA.

24. Lidonga,G (2015). Collapsing Buildings in Nairobi: Who is to Blame? From

http://mwanzoni.com/collapsing-buildings-inkenya-who-is-to-blame/(accessed December, 2017)

25. Lidiema, C (2017) Effects of Government Borrowing on Private Investments in Kenya. Kenya Bankers Association. Working Paper series WPS/06/17.

26. Lutz, B. F. (2008). The connection between house price appreciation and property tax revenues. National Tax Journal, 555-572

27. Maana, I., Owino, R., \&Mutai, N. (2008, June). Domestic Debt and its Impact on the Economy-The Case of Kenya. In 13th Annual African Econometric Society Conference in Pretoria, South Africa from 9th to 11th July.

28. MAINA, A. W. (2014). INCOME TAXES AND ECONOMIC PERFOMANCE IN KENYA(Doctoral dissertation, University of Nairobi).

29. Maingi, N. (2011). The Impact of Government Expenditure on Economic Growth in Kenya; 1963 2008. Deparment of Economics, Kenyatta University.

30. Muigai, M. N. (2016). Impact of Government Expenditure on Gross Domestic Product in Kenya

31. Myers, S. C. (1977). Determinants of corporate borrowing. Journal of financial economics, 5(2), 147-175.

32. Njuru, S. G. (2012). Effects of fiscal policy on private investment in Kenya (1964-2010)(Doctoral dissertation).
33. ONYANGO, J. K. (2014). The impact of external debt on economic growth in kenya (Doctoral dissertation, University of Nairobi)

34. Peacock, A. T., \& Wiseman, J. (1961). Front matter, the growth of public expenditure in the United Kingdom. In The growth of public expenditure in the United Kingdom (pp. 32-0). Princeton University Press

35. Putunoi, G. K., \& Mutuku, C. M. (2013). Domestic debt and economic growth nexus in Kenya. Current Research Journal of Economic Theory, 5(1), 1-10.

36. Robert K.,(2015) The Impact of Domestic Public Debt on Private Investment inKenya IISTE Journal, $4(22)$.

37. Sheikh, M. R., Faridi, M. Z., \& Tariq, K. (2010). Domestic Debt and Economic Growth in Pakistan: An Empirical Analysis. Pakistan Journal of Social Sciences (PJSS), 30(2).

38. Sinevičienè, L. (2015). Testing the Relationship between Government Expenditure and Private Investment: the case of small open economies. Journal of Economics, Business and Management, 3(6), 628-632.

39. Smith, A. (1950). An Inquiry into the Nature and Causes of the Wealth of Nations,(1776). Methuen.

40. Thananga, A. G., Wanyoike, D. M., \&Wagoki, A. J. (2013). Factors Affecting Compliance on Rental Income Tax Policy by Landlords in Nakuru Municipality. Journal of Agriculture and Environmental Sciences, 2(1), 26-38.

41. Teklay,B,(2015) Impact of Government Capital Expenditure on Growth of Private Sector Investment: The Case of Ethiopia.IISTE Journal, 6(4), 2016.

42. Torgler, B. (2007). Tax compliance and tax morale: A theoretical and empirical analysis. Edward Elgar Publishing.

43. Wallace E. Oates.(1969).The Effects of Property Taxes and Local Public Spending on Property Values: An Empirical Study of Tax Capitalization and the TieboutHypothesis.TheJournal of Political Economy,77( 6), pp. 957-971.

44. Were, M. (2001). The impact of external debt on economic growth in Kenya: An empirical assessment (No. 2001/116). WIDER Discussion Papers//World Institute for Development Economics (UNU-WIDER).

45. Were, M., Ngugi, R., Makau, P., Wambua, J., \&Oyugi, L. (2006). Understanding the reform process in Kenya. Understanding economic reforms in Africa: A tale of seven nations, 22-25. 